\title{
ANALYSIS OF PISA-2015 PERFORMANCE OF TURKISH STUDENTS BY MULTILEVEL STRUCTURAL EQUATION MODELING
}

\author{
Ertan AKGENÇ, MSc Student, Graduate School of Natural and Applied Sciences, Selçuk University, Türkiye, ertan57gs@gmail.com \\ (iD) https://orcid.org/0000-0002-9497-6711) \\ *Nimet YAPICI PEHLIVAN, Department of Statistics, Faculty of Science, Selçuk University, Türkiye, nimet@selcuk.edu.tr \\ (D) https://orcid.org/0000-0002-7094-8097) \\ Received: 16.11.2018, Accepted: 15.03.2019 \\ *Corresponding author \\ Research Article \\ DOI: $10.22531 /$ muglajsci.484469
}

\begin{abstract}
The Programme For International Student Assesment (PISA) is an international survey funded by the Organization of Economic Cooperation and Development (OECD). PISA survey is conducted every three years since 2000, to measure and evaluate the educational quality of students aged between 15 and 16. PISA survey is aimed to evaluate students' achievements through the concept of description that they have learned in Science, Mathematics and Reading Skills. In PISA 2015 survey, Science literacy performance of the students were examined. Multilevel Structural Equation Modeling is a multilevel statistical analysis technique used in the analysis of models with complex data structure. Nowadays, , data obtained from many projects such as PISA, TIMSS, and PIRLS, have a complex and hierarchical structure. The MSEM analysis is needed for hierarchical data. The aim of this study is to analyze the created model for PISA 2015 Science Literacy Performance of the Turkish students by using MSEM analysis comparing with the Singaporean students which are the first rank amongst participating countries' students. Turkish and Singapore students were analyzed by using Mplus package program. It has been observed that the model established for both countries is in good fit.

Keywords: Multilevel structural equation modeling, Science literacy, Mplus, PISA 2015

\section{TÜRK ÖĞRENCİLERÍN PISA-2015 PERFORMANSININ COK SEVIYELİ YAPISAL EŞITTLİK MODELLEMESİ İLE ANALİZi}

\section{Özet}

Uluslararası Öğrenci Değerlendirme Programı (PISA), Ekonomik İşbirliği ve Kalkınma Örgütü (OECD) tarafından finanse edilen uluslararası bir araştırmadır. PISA araştırması, 2000 yılından beri her üç yılda bir 15-16 yaş arası öğrencilerin eğitim kalitesini değerlendirmek ve ölçmek amacıyla gerçekleștirilmektedir. PISA araștırması, öğrencilerin Fen Bilimleri, Matematik ve Okuma Becerilerinde öğrendikleri tanım kavramını kullanarak başarılarını değerlendirmeyi amaçlamaktadır. PISA 2015 araştırmasında, öğrencilerin Fen Bilimleri okuryazarlı̆̆ incelenmiştir. Çok seviyeli yapısal eşitlik modellemesi (MSEM), karmaşık veri yapısına sahip modellerin analizinde kullanılan çok seviyeli bir istatistiksel analizdir. Günümüzde, PISA, TIMSS ve PIRLS gibi birçok projeden elde edilen veriler karmaşılk ve hiyerarşik bir yapıdadır. MSEM nalizi hiyerarșik veriler için gereklidir. Bu çalıșmanın amacı, Türk öğrencilerin 2015 PISA araștırması Fen Bilimleri okuryazarlı̆̆ için MSEM analizi kullanılarak oluşturulan modeli analiz etmek ve katılımcı ülkelerin öğrencileri arasında birinci sırada yer alan Singapurlu öğrenciler ile karşılaștırmaktır. Türk ve Singapurlu öğrenciler, MPlus paket programı kullanılarak analiz edilmiştir. Her iki ülke için oluşturulan modellerin iyi uyum gösterdiği gözlenmiştir.

Anahtar Kelimeler: Çok Seviyeli Yapısal Eșitlik Modellemesi, Fen Okuryazarlığı, MPlus, PISA 2015

Cite

Akgenç, E., Yapıcı Pehlivan, N., (2019). “Analysis of PISA-2015 Performance of Turkish Students By Multilevel Structural Equation Modeling", Mugla Journal of Science and Technology, 5 (1)43-51.

\section{Introduction}

In the developing and changing world order, the notion of education is known as one of the most important factors affecting lifestyle. The economic, socio-cultural, contemporary and scientific levels of societies are seen as a reflection of the educational process. The quality of education is evaluated within the scope of various projects at the international level. Turkey has participated in the various international projects which evaluate training performance of the countries such as The Trends in International Mathematics and Science Study (TIMSS), The Progress in International Reading Literacy Study (PIRLS), The Programme for International Student Assesment (PISA).

The Programme For International Student Assesment (PISA) is an international survey conducted to measure and evaluate the educational quality of students [1]. PISA survey has been conducted every three years since the 
year 2000. PISA survey has been funded by the Organization of Economic Cooperation and Development (OECD). The main purpose of the PISA survey is to evaluate students' achievements through the concept of description that they have learned in Science, Mathematics and Reading Skills [2]. PISA survey is applied to the students aged between 15 and 16 years.

\section{Multilevel Structural Equation Modeling}

Structural equation modeling (SEM) is a widely used modeling tool in many areas such as behavioral, commercial and social sciences [3]. SEM is a multivariate statistical analysis which investigates the relationship between multiple results in complex systems with causality [4]. SEM is a modeling method used to test hypotheses based on cause-effect [5].

MSEM is a multilevel statistical analysis technique used in the analysis of models with complex data structure such as social sciences, psychology research and intercultural research [6-10]. Today, data obtained from many projects such as PISA, TIMSS, and PIRLS, have a complex and hierarchical structure. When the data are hierarchical, structural equation modeling analysis is inadequate and multi-level structural equation modeling (MSEM) analysis is needed.

Some of the literatures of MSEM on education studies is given in Table 1.

Table 1. Some of the literatures of MSEM on education studies

\begin{tabular}{|c|c|c|c|c|}
\hline Author & Year & Data & Participants & Method \\
\hline $\begin{array}{l}\text { Goldstein } \\
\text { et al.[11] }\end{array}$ & 2007 & $\begin{array}{l}\text { The } \\
\text { Programme } \\
\text { for } \\
\text { International } \\
\text { Student } \\
\text { Assesment } \\
\text { (PISA) }\end{array}$ & $\begin{array}{l}326 \text { schools } \\
8.299 \\
\text { individual }\end{array}$ & $\begin{array}{l}\text { Markov } \\
\text { Chain } \\
\text { Monte } \\
\text { Carlo } \\
\text { Method } \\
\text { in } \\
\text { MSEM } \\
\end{array}$ \\
\hline $\begin{array}{l}\text { Can et } \\
\text { al.[12] }\end{array}$ & 2011 & $\begin{array}{l}\text { Test of } \\
\text { Nonverbal } \\
\text { Intelligent } \\
\text { (TONI-3) }\end{array}$ & $\begin{array}{l}39 \text { schools } \\
381 \\
\text { students }\end{array}$ & MSEM \\
\hline $\begin{array}{l}\text { Davidov } \\
\text { et al. [7] }\end{array}$ & 2012 & $\begin{array}{l}\text { European } \\
\text { Social Survey } \\
\text { (ESS) }\end{array}$ & $\begin{array}{l}25 \\
\text { countries } \\
43.779 \\
\text { individual } \\
\end{array}$ & MSEM \\
\hline Atar[13] & 2014 & $\begin{array}{l}\text { Trends in } \\
\text { International } \\
\text { Mathematics } \\
\text { and Science } \\
\text { Study } \\
\text { (TIMMS) }\end{array}$ & $\begin{array}{l}239 \text { schools } \\
6.928 \\
\text { individual }\end{array}$ & MSEM \\
\hline
\end{tabular}

In MSEM, both the between and within-group variancecovariance matrix are evaluated simultaneously. MSEM is a two-level analysis method including within-group and between-group levels [14]. The between group level (i.e. level 2) contains clusters such as countries, schools, faculties, regions, classes, etc. The within group level (i.e. level 1) contains individuals belonging to clusters such as students, teachers, workers, etc.

MSEM decomposes a structural model into within-group and between-group as follows:

Within group: $\eta_{W g i}=B_{W} \eta_{W i g}+\zeta_{W i g}$

Between groups: $\eta_{B g}=\alpha_{g}+B_{B} \eta_{B g}+\zeta_{B g}$

Where,

$g$ : groups,

$i$ : individuals

B : structural regression coefficients,

$\alpha_{g}:$ residual terms vector,

$\zeta$ : the vector consists of (random) cut points,

$\eta$ : latent variable [15-17].

Path diagram of the multi-level structural equation model is illustrated in Figure $1[12,18]$.

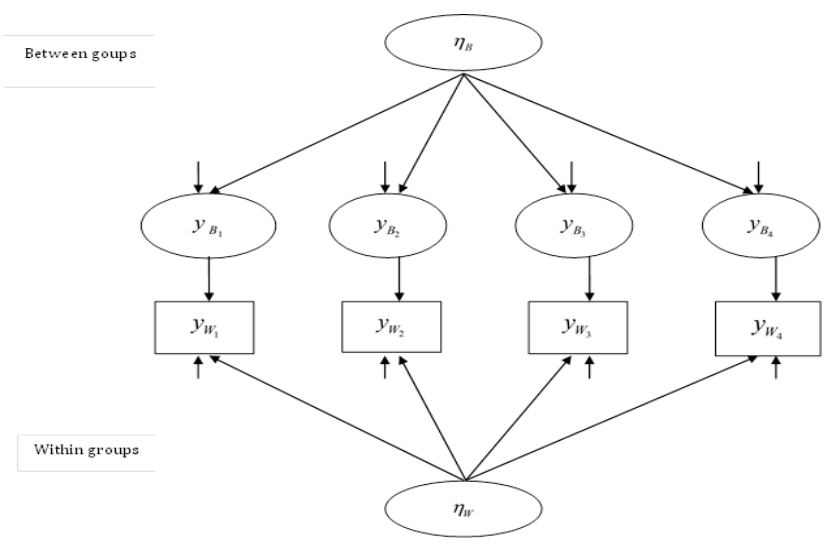

Figure 1. Path diagram of the multi-level structural equation model

It should be determined whether the model created in MSEM is a good fit or acceptable fit. Commonly used goodness of fit indices in the MSEM are Comparative Fit Index (CFI), Tucker Lewis Index (TLI), Root Mean Square Error of Approximation (RMSEA) and Standardized Root Mean Residual (SRMR). These indices are shown in Table 2 [19-26].

Table 2. Goodness of fit indices used in MSEM Goodness of fit index Good fit / Acceptable fit

CFI $\geq 0.97$ good fit /
$\geq 0.95$ acceptable fit.

TLI $\geq 0.95$ good fit / 0.94-0.90 acceptable fit.

RMSEA $\leq 0.05$ good fit / 0.06-0.08 acceptable fit

SRMR 0.06-0.08 acceptable fit. 


\section{Application}

In order to examine the PISA 2015 data with the multilevel structural equation modeling (MSEM), at first socio demographic results were obtained by IBM SPSS Statistic 21.0 version. Then, MPlus Program Version 5.1 (32-bit) was used for multi-level structural equation modeling analysis.

It is possible to analyze over-developed, multilevel, latent class and complex models through the Mplus software $[20,27]$.

In PISA 2015 survey for Turkey, 187 schools (between groups) and 5895 students (within-group) were chosen by stratified random sampling method. For the MSEM analysis, dependent and independent variables are given as follows:

Dependent variable:

Y: Science achievement score (SAS)

Independent variables (Within-group):

Selected from the student questionnaire as follows:

X1: Gender

X2: Family support

X3: Science working hours

X4: Activity in science class

X5: Teacher's comment in science class

X6: Teacher support in science class

X7: Science self-concept

X8: Interest in science

X9: Science activities

X10: Program type

Independent variables (Between-groups):

Selected from the school questionnaire as follows:

X11: Settlement

X12: Number of smart boards

X13: Science equipment

X14: Laboratory

X15: Laboratory material

X16: School type

X17: Teaching hours

Class variable;

Clus: Number of schools.

\section{Results}

In the PISA 2015 survey, Science literacy performance of the students were examined. In this study, at first, descriptive statistics of the variables in the model were evaluated. Then, model fitting of the created model was evaluated.

Descriptive statistics for Turkey are shown in Table 3. Constructed model of the MSEM for Turkey is given as:

$Y_{i j}=\gamma_{00}+\gamma_{10} X 1+\gamma_{20} X 2+\gamma_{30} X 3+\gamma_{40} X 4+\gamma_{50} X 5+\gamma_{60} X 6$

$+\gamma_{70} X 7+\gamma_{80} X 8+\gamma_{90} X 9+\gamma_{100} X 10+\gamma_{01} X 11+\gamma_{02} X 12$

$+\gamma_{03} X 13+\gamma_{04} X 14+\gamma_{05} X 15+\gamma_{06} X 16+\gamma_{07} X 17+\tau_{0 j}+e_{i j}$
The path diagram of the MSEM for Turkey is shown in Figure 2.

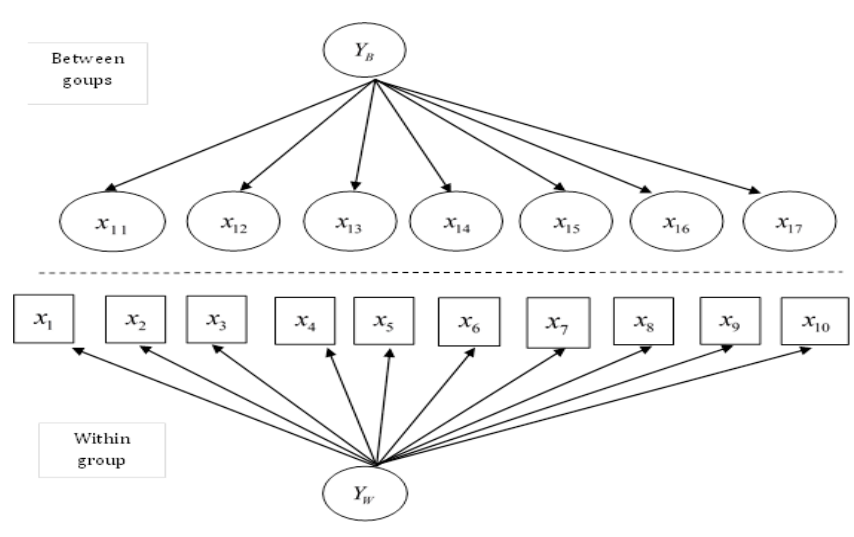

Figure 2. The path diagram of the MSEM for Turkey

Mplus multilevel structural equation modeling results for Turkey is given in Table 4 .

When the within-group results of the Mplus program for Turkey are examined, the science achievement score $(\mathrm{Y})$ of the students do not vary according to the following variables;

-teacher's comment in science class $(\mathrm{X} 5=0.235>\mathrm{p}=$ 0.05)

-program type $(\mathrm{X} 10=0.750>\mathrm{p}=0.05)$

Variables affecting the science achievement score $(\mathrm{Y})$ are as follows:

-gender $(\mathrm{X} 1=0.002<\mathrm{p}=0.05)$,

-family support ( $\mathrm{X} 2=0.000<\mathrm{p}=0.05)$,

-science working hours (X3=0.000 $<\mathrm{p}=0.05)$,

-activities in science class ( $\mathrm{X} 4=0.000<\mathrm{p}=0.05)$,

-teacher support in science course $(X 6=0.000<p=0.05)$,

-science self-concept $(X 7=0.000<p=0.05)$,

-interest in science $(X 8=0.000<p=0.05)$

-science activities ( $\mathrm{X} 9=0.000<\mathrm{p}=0.05)$.

When the between-group results of the Mplus program for Turkey are examined, the science achievement score $(\mathrm{Y})$ varies according to the following variables

-settlement $(\mathrm{X} 11=0.048<\mathrm{p}=0.05$,

-number of smart boards $(\mathrm{X} 12=0.000<\mathrm{p}=0.05)$

-science equipment variables (X13=0.043<p=0.05).

Other variables obtained from the school questionnare do not affect the science achievement score $(\mathrm{Y})$;

-laboratory (X14 $=0.784>\mathrm{p}=0.05)$.

-laboratory material $(X 15=0.140>p=0.05)$.

-type of school (X16 $=0.229>\mathrm{p}=0.05)$.

-teaching hours (X17 $=0.528>p=0.05)$.

Goodness of fit indices of the created model for Turkey are obtained as;

$-\mathrm{CFI}=1.000 \quad(>0.97$ good fit $)$ 
$-\mathrm{TLI}=1.000 \quad(>0.95$ good fit $)$

- RMSEA $=0.000 \quad(<0.05$ good fit $)$

$-\mathrm{SRMR}=0.000(<0.05$ good fit $)$

According to these results, it is determined that the created model for Turkey is a multi-level structural equation model with good fit [28].

In PISA 2015, the mean score in science for OECD countries is 493 points. Singapore with a mean score of 556 points, outperforms all other participating countries in science.

In a similar manner, MSEM analysis are conducted on Singaporean students. Created model expressed by " $Y_{i j}$ " for Singapore is;

$Y_{i j}=\gamma_{00}+\gamma_{10} X 1+\gamma_{20} X 2+\gamma_{30} X 3+\gamma_{40} X 4+\gamma_{50} X 5+\gamma_{60} X 6$

$+\gamma_{70} X 7+\gamma_{80} X 8+\gamma_{90} X 9+\gamma_{100} X 10+\gamma_{01} X 11+\gamma_{02} X 12$

$+\gamma_{03} X 13+\gamma_{04} X 14+\gamma_{05} X 15+\tau_{0 j}+e_{i j}$

Descriptive statistics for Singapore are shown in Table 5. The path diagram of the MSEM for Singapore is illustrated in Figure 3.

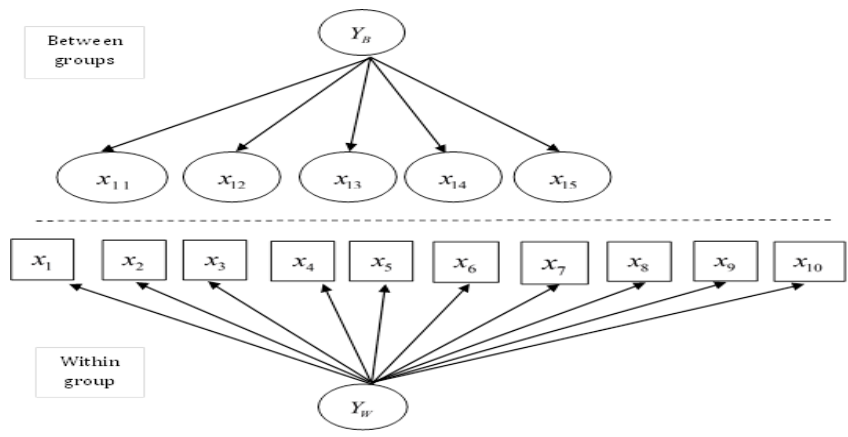

Figure 3. The path diagram of the MSEM for Singapore

Mplus multilevel structural equation modeling results for Singapore is given in Table 6.

The science achievement score $(\mathrm{Y})$ of the Singaporean students do not vary according to the following variables; -family support $(\mathrm{X} 2=0.359>\mathrm{p}=0.05)$

-teacher support in science class (X6 $=0.645>p=0.05$ )

Variables affecting the science achievement score $(\mathrm{Y})$ are as follows:

-gender $(\mathrm{X} 1=0.006<\mathrm{p}=0.05)$,

-study hours in science $(X 3=0.047<\mathrm{p}=0.05)$,

-activities in science class ( $\mathrm{X} 4=0.000<\mathrm{p}=0.05)$,

-teacher's comment in science class $(X 5=0.010<\mathrm{p}=0.05)$,

-science self-concept $(X 7=0.000<p=0.05)$,

-interest in science (X8=0.000 $<\mathrm{p}=0.05)$,

-science activities $(\mathrm{X} 9=0.000<\mathrm{p}=0.05)$

Table 3. Descriptive statistics for Turkey -program type $(\mathrm{X} 10=0.000<\mathrm{p}=0.05)$.

When the between-group results of the Mplus program for Singapore are examined, the science achievement score $(\mathrm{Y})$ varies according to the following variables

- number of smart boards (X11 $=0.001<\mathrm{p}=0.05)$.

- school type $(X 14=0.000<p=0.05)$.

- teaching hours (X15 $=0.000<p=0.05)$.

Other variables obtained from the school questionnare do not affect the science achievement score (Y);

- science equipment (X12 $=0.890>\mathrm{p}=0.05)$.

- laboratory $(\mathrm{X} 13=0.083>\mathrm{p}=0.05)$.

Goodness of fit indices of the created model for Singapore are obtained as;

$-\mathrm{CFI}=1.000 \quad(>0.97$ good fit $)$

$-\mathrm{TLI}=1.000 \quad(>0.95 \operatorname{good} \mathrm{fit})$

-RMSEA $=0.000 \quad(<0.05$ good fit $)$

- SRMR $=0.000(<0.05$ good fit $)$

According to these results, it is determined that the model created for Singapore is a multi-level structural equation model with good fit [28]. 


\begin{tabular}{|c|c|c|c|c|c|c|}
\hline Variables & Frequency & $\begin{array}{c}\text { Percenta } \\
\text { ge (\%) }\end{array}$ & Mean & $\begin{array}{l}\text { Standard } \\
\text { Deviation }\end{array}$ & $\begin{array}{c}\text { Min. } \\
\text { Value }\end{array}$ & $\begin{array}{c}\text { Max. } \\
\text { Value }\end{array}$ \\
\hline Gender (X1) & 5895 & & & & 1 & 2 \\
\hline Female (1) & 2938 & 49.8 & & & & \\
\hline Male (2) & 2957 & 50.2 & & & & \\
\hline Family support (X2) & 5895 & & 12.86 & 2.87 & 1 & 16 \\
\hline Study hours in science (X3) & 5895 & & 5.34 & 4.37 & 0 & 30 \\
\hline Activity in science class (X4) & 5895 & & 10.59 & 3.12 & 1 & 16 \\
\hline Teacher's comment in science class (X5) & 5895 & & 9.90 & 2.85 & 2 & 16 \\
\hline Teacher support in science class (X6) & 5895 & & 7.38 & 2.28 & 1 & 12 \\
\hline Science self-concept(X7) & 5895 & & 13.32 & 4.17 & 1 & 20 \\
\hline Interest in science (X8) & 5895 & & 12.78 & 4.31 & 1 & 25 \\
\hline Science activities (X9) & 5895 & & 26.36 & 7.07 & 1 & 36 \\
\hline Program type (X10) & 5895 & & & & 1 & 3 \\
\hline Basic education (1) & 121 & 2.1 & & & & \\
\hline General secondary education (2) & 3241 & 55.0 & & & & \\
\hline Vocational and Technical sec. edu. (3) & 2533 & 43.0 & & & & \\
\hline Settlement (X11) & 5895 & & 3.96 & 1.01 & 1 & 5 \\
\hline A village, a village or a rural area (1) & 72 & 1.2 & & & & \\
\hline Small town (2) & 372 & 6.3 & & & & \\
\hline One town (3) & 1776 & 30.1 & & & & \\
\hline One city (4) & 1286 & 21.8 & & & & \\
\hline Great city (5) & 2385 & 40.5 & & & & \\
\hline Number of smart boards (X12) & 5895 & & 21 & 16 & 0 & 60 \\
\hline Science equipment (X13) & 5895 & & & & 1 & 2 \\
\hline Yes (1) & 1618 & 27.4 & & & & \\
\hline No $(2)$ & 4277 & 72.6 & & & & \\
\hline Laboratory (X14) & 5895 & & & & 1 & 2 \\
\hline Yes (1) & 1769 & 30.0 & & & & \\
\hline No $(2)$ & 4126 & 70.0 & & & & \\
\hline Laboratory material (X15) & 5895 & & & & 1 & 2 \\
\hline Yes (1) & 1716 & 29.1 & & & & \\
\hline No (2) & 4179 & 70.9 & & & & \\
\hline School type (X16) & 5895 & & & & 1 & 2 \\
\hline Public school (1) & 5653 & 95.9 & & & & \\
\hline Private school (2) & 242 & 4.1 & & & & \\
\hline ing hours(X17) & 5895 & & 7.13 & 5.97 & 1 & 53 \\
\hline Clus (Class) & 187 & & & & & \\
\hline Science achievement score (SAS) & 5895 & & 422.45 & 77.13 & 197.7 & 707.9 \\
\hline
\end{tabular}

Table 4. Mplus multilevel structural equation modeling results for Turkey

\begin{tabular}{|c|c|c|c|c|}
\hline Variables & Estimation & $\begin{array}{c}\text { Standard } \\
\text { error }\end{array}$ & $\begin{array}{c}\text { Estimation/ } \\
\text { Standard error }\end{array}$ & p value \\
\hline \multicolumn{5}{|l|}{ Independent variable } \\
\hline Science achievement score $(\mathrm{Y})$ & 421.869 & 31.674 & 13.319 & $0.000^{*}$ \\
\hline \multicolumn{5}{|l|}{ Within-group variables } \\
\hline Gender (X1) & 0.054 & 0.017 & 3.144 & $0.002 *$ \\
\hline Family support (X2) & 0.049 & 0.013 & 3.729 & $0.000 *$ \\
\hline Study hours in science (X3) & -0.076 & 0.014 & -5.635 & $0.000 *$ \\
\hline Activity in science class (X4) & 0.114 & 0.013 & 8.425 & $0.000 *$ \\
\hline Teacher's comment in science class (X5) & 0.016 & 0.014 & 1.187 & 0.235 \\
\hline Teacher support in science class (X6) & 0.077 & 0.014 & 5.563 & $0.000 *$ \\
\hline Science self-concept (X7) & 0.116 & 0.014 & 8.341 & $0.000^{*}$ \\
\hline Interest in science (X8) & 0.051 & 0.014 & 3.656 & $0.000 *$ \\
\hline Science activities (X9) & 0.091 & 0.014 & 6.499 & $0.000 *$ \\
\hline Program type (X10) & -0.017 & 0.054 & -0.319 & 0.750 \\
\hline \multicolumn{5}{|l|}{ Between-groups variables } \\
\hline Settlement (X11) & 0.150 & 0.076 & 1.966 & $0.048^{*}$ \\
\hline Number of smart boards (X12) & 0.282 & 0.062 & 4.563 & $0.000^{*}$ \\
\hline
\end{tabular}




\begin{tabular}{rcccc} 
Science equipment (X13) & -0.229 & 0.123 & -1.856 & $0.043^{*}$ \\
Laboratory (X14) & 0.033 & 0.121 & 0.274 & 0.784 \\
Laboratory material (X15) & -0.147 & 0.100 & -1.476 & 0.140 \\
School type (X16) & 0.073 & 0.060 & 1.204 & 0.229 \\
Teacher working time (X17) & -0.030 & 0.047 & -0.632 & 0.528 \\
\hline
\end{tabular}

*p value $<0.05$

Table 5. Descriptive statistics for Singapore

\begin{tabular}{|c|c|c|c|c|c|c|}
\hline Variables & Frequency & $\begin{array}{l}\text { Percentage } \\
(\%)\end{array}$ & Mean & $\begin{array}{l}\text { Standard } \\
\text { Deviation }\end{array}$ & $\begin{array}{l}\text { Min. } \\
\text { Value }\end{array}$ & $\begin{array}{l}\text { Max. } \\
\text { Value }\end{array}$ \\
\hline Gender (X1) & 6115 & & & & 1 & 2 \\
\hline Female (1) & 2973 & 48.6 & & & & \\
\hline Male (2) & 3142 & 51.4 & & & & \\
\hline Family support (X2) & 6115 & & 13.03 & 2.43 & 2 & 16 \\
\hline Science working hours (X3) & 6115 & & 6.15 & 4.88 & $\mathbf{0}$ & 30 \\
\hline Activity in science class (X4) & 6115 & & 11.64 & 3.25 & 3 & 16 \\
\hline Teacher's comment in science class (X5) & 6115 & & 11.59 & 3.59 & 3 & 16 \\
\hline Teacher support in science class $(\mathrm{X} 6)$ & 6115 & & 8.61 & 2.75 & 2 & 12 \\
\hline Science self-concept (X7) & 6115 & & 15.01 & 3.42 & 2 & 20 \\
\hline Interest in science (X8) & 6115 & & 14.35 & 3.71 & 2 & 25 \\
\hline Science activities (X9) & 6115 & & 29.7 & 5.6 & 3 & 36 \\
\hline Program type (X10) & 6115 & & & & 1 & 3 \\
\hline Basic education (1) & 113 & 1.8 & & & & \\
\hline General secondary education (2) & 5993 & 98.0 & & & & \\
\hline Vocational and Technical sec. edu. (3) & 9 & 0.2 & & & & \\
\hline Number of smart boards (X11) & 6115 & & 5 & 9 & $\mathbf{0}$ & 85 \\
\hline Science equipment (X12) & 6115 & & & & 1 & 2 \\
\hline Yes (1) & 5844 & 95.6 & & & & \\
\hline No (2) & 271 & 4.4 & & & & \\
\hline Laboratory (X13) & 6115 & & & & 1 & 2 \\
\hline Yes (1) & 5372 & 87.8 & & & & \\
\hline No (2) & 743 & 12.2 & & & & \\
\hline School type (X14) & 6115 & & & & 1 & 2 \\
\hline Public School (1) & 5717 & 93.5 & & & & \\
\hline Private School (2) & 398 & 6.5 & & & & \\
\hline Teacher working time (X15) & 6115 & & 18.5 & 9.6 & 4 & 89 \\
\hline Clus (Class) & 177 & & & & & \\
\hline Science achievement score (Y) & 6115 & & 546.39 & 104.5 & 228 & 888 \\
\hline
\end{tabular}

Table 6. Mplus multilevel structural equation modeling results for Singapore

\begin{tabular}{lcccc}
\hline Variables & Estimation & $\begin{array}{c}\text { Standard } \\
\text { error }\end{array}$ & $\begin{array}{c}\text { Estimation/ } \\
\text { Standard error }\end{array}$ & p value \\
\hline $\begin{array}{l}\text { Independent variable } \\
\text { Science achievement score (Y) }\end{array}$ & 456.474 & 26.629 & 17.142 & $0.000^{*}$
\end{tabular}

Within-group variables 


\begin{tabular}{rcccc} 
Gender (X1) & 0.008 & 0.013 & 0.603 & $0.006^{*}$ \\
Family support (X2) & 0.013 & 0.014 & 0.917 & 0.359 \\
Science working hours (X3) & 0.019 & 0.013 & 1.415 & $0.047^{*}$ \\
Activity in science class (X4) & -0.109 & 0.015 & -7.381 & $0.000^{*}$ \\
Teacher's comment in science class (X5) & -0.049 & 0.019 & -2.559 & $0.010^{*}$ \\
Teacher support in science class (X6) & -0.009 & 0.019 & -0.461 & 0.645 \\
Science self-concept (X7) & 0.271 & 0.014 & 19.076 & $0.000^{*}$ \\
Interest in science (X8) & 0.096 & 0.016 & 6.171 & $0.000^{*}$ \\
Science activities (X9) & 0.101 & 0.016 & 6.378 & $0.000^{*}$ \\
Program type (X10) & 0.131 & 0.013 & 9.910 & $0.000^{*}$ \\
Between-groups variables & & & & $0.001^{*}$ \\
Number of smart boards (X11) & -0.202 & 0.058 & -3.465 & 0.890 \\
Science equipment (X12) & 0.009 & 0.068 & 0.138 & 0.083 \\
Laboratory (X13) & -0.115 & 0.067 & -1.731 & $0.000^{*}$ \\
School type (X14) & 0.210 & 0.053 & 3.981 & $0.000^{*}$ \\
\hline
\end{tabular}

\section{Conclusion}

It is known that the education is one of the most important factors affecting the lifestyle in the developing and changing world order. Nowadays, it is known that multilevel structural equation modeling analysis has been widely used in international researches such as PISA, TIMSS and PIRLS. The Mplus program has effectively used for the analysis of the hierarchical data in multilevel structural equation modeling.

When PISA 2015 science literacy results for Turkish students are evaluated, it could be said that the success in the science test of the Turkish students is affected by 8 variables taken from the student questionnaire and is affected by 3 variables from the school questionnaire.

- According to the student questionnaire; Gender, family support, activity in science class, teacher support in the science class, science self-concept, interest in science, and science activities increase the science achievement score of Turkish students. However, the increase in science working hours negatively affects the science achievement score.

- According to the school questionnaire; Science achievement score of Turkish students is increased according to the settlement and number of smart boards. However, decrease in the science equipment in the schools causes science achievement scores to decrease.
When PISA 2015 science literacy results for Singaporean students are evaluated, it could be said that the success in the science test of the Singaporean students is affected by 8 variables taken from the student questionnaire and is affected by 3 variables from the school questionnaire.

- According to the student questionnaire; Gender, science working hours, science self-concept, interest in science, science activities and program type increase the science achievement score of Singaporean students. However, the increase in activity in science class and teacher's comment in science class negatively affects the science achievement score.

- According to the school questionnaire; Science achievement score of Singaporean students has increased with school type and teaching hours. However, decrease in the number of smart boards in schools causes science achievement scores to decrease.

According to the report on PISA 2015 results [2], Singaporean students surpassed all other participating countries/economies in science with mean score 556. Turkish students with mean score 425 ranked as 52 among the 72 participating countries. In Turkey, the course density was observed to be high. Therefore, students' interest in science has decreased. However, the lower course density has increased the science achievement score in Singapore.

In addition, students with higher study hours $(6.15 \pm 4.88)$ in Singapore are more successful than 
Turkish students with the same study hours (5.34 44.37). It was observed that working hours of Turkish teachers $(7.13 \pm 5.97)$ had no effect on science achievement score of Turkish students, but the working hours of Singaporean teachers $(18.5 \pm 9.6)$ affected the science achievement score of Singaporean students positively. Although the impact of family support to students is high in Turkey, science achievement scores of Turkish students are lower than the Singaporean students.

As a result, difference between the Turkish students and Singaporean students is obvious in terms of science achievement score. For this reason, it can be suggested that the Turkish education system should be revised by examining the Singapore education system in detailed.

\section{Acknowledgment}

The earlier and initial version of this study presented at ISDC2018 Congress by Nimet Yapıcı Pehlivan. This study is a part of M.Sc. Thesis titled "Multilevel Structural Equation Modeling and An Application" prepared by Ertan Akgenç in Selçuk University, Graduate School of Natural and AppliedSciences.

\section{References}

[1] Taş, U.E., PISA 2015 ulusal raporu, Ankara, MEB, 2016.

[2] OECD. 2016, PISA 2015 Results (Volume I).

[3] Barrett, P., "Structural equation modelling: Adjudging model fit", Personality and Individual Differences, Vol.42 No.5, 815-824, 2007.

[4] Cha, E., Sanderson, M., Renter, D., Jager, A., Cernicchiaro, N., Bello, N.M., "Implementing structural equation models to observational data from feedlot production systems", Preventive veterinary medicine, Vol.147 163-171, 2017.

[5] Alkış, N., "Bayes Yapısal Eşitlik Modellemesi: Kavramlar ve Genel Bakıș", Gazi Íktisat ve Isşletme Dergisi, Vol.2 No.3, 105-116, 2016.

[6] Acar, T. Öğretmen, T., “Çok düzeyli istatistiksel yöntemler ile 2006 PISA fen bilimleri performansının incelenmesi", Eğitim ve Bilim, Vol. 37 No.163, 178-189 2012.

[7] Davidov, E., Dülmer, H., Schlüter, E., Schmidt, P., Meuleman, B., "Using a multilevel structural equation modeling approach to explain crosscultural measurement noninvariance", Journal of Cross-Cultural Psychology, Vol.43 No.4, 558-575, 2012.

[8] Holtmann J., Koch T., Lochner K., Eid M., "A Comparison of ML, WLSMV, and Bayesian Methods for Multilevel Structural Equation Models in Small Samples: A Simulation Study", Multivariate behavioral research, Vol. 51 No. 5, 661-680, 2016.

[9] Hox, J.J., van de Schoot, R. Matthijsse, S., "How few countries will do? Comparative survey analysis from a Bayesian perspective", Survey Research Methods, Vol.6 No.2, 87-93, 2012.

[10] Peugh, J. L. ve Enders, C. K., "Specification searches in multilevel structural equation modeling: A Monte
Carlo investigation", Structural equation modeling, Vol.17 No.1, 42-65, 2010.

[11] Goldstein, H., Bonnet, G. ve Rocher, T., "Multilevel structural equation models for the analysis of comparative data on educational performance", Journal of Educational and Behavioral Statistics, Vol. 32 No. 3, 252-286, 2007.

[12] Can, S., Somer, O., Korkmaz, M., Dural, S., Öğretmen, T., "Çok Düzeyli Yapısal Eşitlik Modelleri”, Türk Psikoloji Dergisi, Vol.26 No.67, 14-21, 2011.

[13] Atar, H.Y., "Öğretmen niteliklerinin TIMSS 2011 fen bașarısına çok düzeyli etkileri”, Eğitim ve Bilim, Vol.39 No.172, 121-137, 2014.

[14] Kaplan, D., Structural equation modeling: Foundations and extensions, (Vol. 10), Sage Publications, 2008.

[15] Heck, R. H., (Editors Marcoulides, G.A., Schumacker, R.E.), "Multilevel modeling with SEM", New developments and techniques in structural equation modeling, 89-127, 2001.

[16] Hox, J.J., Multilevel analysis: Techniques and applications, Lawrance Erlbaum Associates Inc. Publishers, New Jersey, 2002.

[17] Hox, J.J., Applied multilevel analysis, TT-publikaties, Amsterdam, 1995.

[18] Dyer, N.G., Hanges, P.J. , Hall, R.J., "Applying multilevel confirmatory factor analysis techniques to the study of leadership", The leadership quarterly, Vol.16 No.1, 149-167, 2005.

[19] Hoyle, R.H., Structural equation modeling: Concepts, issues, and applications, Sage, London, 1995.

[20] Schreiber, J. B., "Core reporting practices in structural equation modeling, Research in social and administrative pharmacy, Vol.4 No.2, 83-97, 2008.

[21] Lee, S.Y., Song, X.Y., "Structural Equation Models A2" - Peterson, Penelope, In E. Baker, B. McGaw (Eds.), International Encyclopedia of Education (Third Edition), Oxford, Elsevier, 453-458, 2010.

[22] Taşkın, Ç., Akat, Ö., Araştırma yöntemlerinde yapısal eșitlik modelleme: LISREL ile marka değeri ölçümü örnekleri, Ekin Basım Yayın Dă̆ıtım, Bursa, 2010.

[23] Meydan, C.H., Şeşen, H., Yapısal eşitlik modellemesi AMOS uygulamaları, Detay Yayıncılık, Ankara, 2011.

[24] Çokluk, Ö., Şekercioğlu, G. Büyüköztürk, Ş., Sosyal bilimler için çok değişkenli istatistik: SPSS ve LISREL uygulamaları, Pegem Akademi, Ankara, 2012.

[25] Ryu, E., "Effects of skewness and kurtosis on normaltheory based maximum likelihood test statistic in multilevel structural equation modeling", Behavior research methods, Vol.43 No.4, 1066-1074, 2011.

[26] Ghanizadeh, A. Jahedizadeh, S., "EFL teachers' teaching style, creativity, and burnout: A path analysis approach", Cogent Education, Vol.3 No.1, 1151997, 2016.

[27] Muthén, L. K., Muthén, B. O., Mplus User's guide: Statistical analysis with latent variables, Sixth Edition, Los Angeles, 1998. 
[28] Akgenç, E., Çok seviyeli yapısal eşitlik modellemesi ve bir uygulama, Yüksek Lisans Tezi, Selçuk Üniversitesi, Fen Bilimleri Enstitüsü, Konya, 2018. 